\title{
Notas etnográficas sobre o futebol de várzea
}

\author{
Luiz Carlos Rigo* \\ Luciano Jahnecka** \\ Inácio Crochemore da Silva***
}

\begin{abstract}
Resumo: Este estudo tem como objetivo descrever e analisar o atual estado do futebol de várzea (futebol amador, de bairro) na cidade de Pelotas, Brasil. Através da etnografia interpretativa, por meio de observações (registros escritos e fotografias), entrevistas semi-estruturadas e da análise de documentos, realizamos um estudo detalhado do Campeonato Praiano e do Campeonato Citadino, as duas principais competições organizadas pela Liga Pelotense de Futebol Amador (LPFA). Concluímos que em Pelotas o futebol de várzea está longe de acabar. Reinventado, ele continua a ser uma das principais práticas de lazer esportivo das classes trabalhadoras da cidade.
\end{abstract}

Palavras-chave: Futebol. Atividades de Lazer. Socialização.

\section{UM FUTEBOL PERSISTENTE}

Em 1995, por teimosia, resolvi organizar um grande campeonato só para times de várzea e esqueci de estabelecer um número limite de participantes. Quando soube que as inscrições passavam de mil times e só existiam 120 vagas, corri a fazer uma eliminatória, tomando o cuidado de nos anos seguintes estabelecer critérios que truncassem tal explosão. (ADAUTO, 1999, p. 122).

\footnotetext{
*Graduado em Educação Física. Mestre em Ciência do Movimento Humano. Doutor em Educação (UNICAMP). Professor Associado da Universidade Federal de Pelotas vinculado a Graduação, Especialização e Mestrado. Tutor do Grupo PET/ESEF. Pelotas, RS, Brasil. E-mail: Icrigo@terra.com.br

**Graduado em Educação Física pela Universidade Federal de Pelotas. Mestre em Ciências (UFRGS). Pelotas, RS, Brasil. E-mail: jahnecka@ibest.com.br

*** Mestrando do Programa de Pós-Graduação em Epidemiologia da Universidade Federal de Pelotas (UFPel). Pelotas, RS, Brasil. E-mail: inacio_cms@yahoo.com.br
} 
Essa citação é parte de um ensaio escrito pelo jornalista Flávio Adauto, publicado no Jornal A Gazeta Esportiva, em 6 de maio de 1999, e reproduzido no livro Futebol: Espetáculo do Século (1999). No texto, o autor contrapõe-se aos discursos que falam do fim do futebol de várzea ${ }^{1}$ no Brasil. Referendando-se em dados empíricos, ele mostra que, na cidade de São Paulo, por exemplo, continua existindo um grande número de equipes que anualmente disputam os campeonatos de várzea. Assim, sem desconsiderar as mudanças políticas, culturais e territoriais pelas quais passaram os espaços públicos de lazer e de prática do futebol, Flávio Adauto (1999, p. 122) atentamente assinala que, ao contrário daquilo que muitos pensam, esse futebol não morreu, ele apenas modificou-se, e lembra que "[...] ainda são centenas os campos de várzea, milhares os times, muitos deles com 50, 60, 70 anos de vida sem nunca interromper suas atividades. Com muita história para contar"2.

A presença do futebol de várzea nas cidades modernas não é uma exclusividade das grandes metrópoles e tampouco da cidade de São Paulo. De um modo geral, as práticas do futebol como lazer, continuam a ter presença marcante, tanto nos grandes centros urbanos como nas médias e pequenas cidades brasileiras, ou ainda nas zonas rurais, onde, não raramente, ele é um dos poucos acontecimentos de lazer dos finais de semana ${ }^{3}$.

\footnotetext{
${ }^{1}$ Futebol de Várzea é um termo usado principalmente na região sul e sudeste do Brasil. Neste artigo ele será utilizado para nomear as competições futebolísticas que apresentam uma organização e um sistema de regramento próprio, apesar de, em muitos aspectos, inspiraremse no futebol profissional. Maiores considerações sobre o conceito de futebol de várzea e a sua diferenciação perante outras manifestações futebolísticas podem ser encontradas no estudo de Arlei Damo: (DAMO, 2003). Nesse artigo Damo propõe uma classificação em que diferencia as práticas do futebol em: Futebol Profissional; Futebol Escolar; Futebol de Bricolagem; e Futebol Comunitário, que corresponderia ao Futebol de Várzea. Recentemente Arlei Damo retomou esta discussão e assinalou que a maior parte da diversidade dos "futebóis" poderia ser agrupada em: matriz bricolada; matriz espetacularizada; matriz comunitária; e matriz escolar (DAMO, 2007).

${ }^{2}$ Os discursos pessimistas que falam de um possível fim do futebol de várzea, a que Flávio Adauto refere-se, encontram adeptos tanto na imprensa esportiva como no meio acadêmico. Um exemplo pode ser encontrado no livro MURAD, 1996. E também no artigo PIMENTA, 2000. ${ }^{3}$ Especificamente sobre o futebol de várzea em Porto Alegre, consultar a dissertação de mestrado de Silvia Regina Godinho Bauler, O futebol faz rolar mais do que uma bola: um estudo sobre o significado do futebol numa periferia urbana. Dissertação de Mestrado, Universidade Federal do Rio Grande do Sul, Programa de Pós-graduação em Educação Física, Porto Alegre, 2005.
} 
Em Pelotas, no Rio Grande do Sul, há muito tempo o futebol ocupa um lugar de destaque no corpo social e na cultura. Pesquisas assinalam que isso começou a ocorrer a partir de 1920, quando houve uma multiplicação de clubes e de equipes avulsas de futebol na cidade $^{4}$.

Tomando como referência a tradição futebolística da cidade e a situação atual do futebol de várzea em nosso País, decidimos fazer este estudo, que trata especificamente da situação do futebol de várzea em Pelotas, RS. O estudo é uma análise do Campeonato Praiano e do Citadino, os dois principais eventos organizados anualmente pela Liga Pelotense de Futebol Amador (LPFA).

\section{Considerações teóRICAS E METOdológICAS}

Aliado ao suporte empírico, este estudo teve também a companhia de alguns autores. Nos apropriamos desses autores e os utilizamos como se eles fossem uma "caixa de ferramenta" (FOUCAULT, 1979) 5 , capaz de auxiliar-nos à alcançar os objetivos do nosso estudo. Neste sentido, destacamos aqui as contribuições que fomos buscar em Clifford Geertz (1989, 2000), principalmente quando ele fala da "natureza microscópica" (GEERTZ, 1989, p. 17) da etnografia, e da possibilidade interpretativa das práticas culturais. Geertz (1989) sugere que:

[...] a diferença, relativa em qualquer caso, que surge nas ciências experimentais ou observacionais

\footnotetext{
${ }^{4} \mathrm{O}$ ano de 1906 pode ser considerado o marco da emergência de clubes esportivos e de futebol em Pelotas. É nesse ano que são fundados o Club Esportivo, o Internacional Sport Club e o Foot-Ball Club. Posteriormente, em 1913, tem início o Campeonato da Cidade e, em 1919, o Grêmio Esportivo Brasil vence o primeiro Campeonato Estadual organizado pela Federação Gaúcha de Futebol. Em 1920, existiam, na cidade, três ligas distintas de futebol: A Liga Pelotense de Futebol, fundada em 1907, da qual faziam parte os maiores clubes da cidade; a Liga Cassiano do Nascimento, organizada em 1914, que correspondia a uma segunda divisão da liga anterior; e a Liga José do Patrocínio, fundada em 1919, da qual participavam somente times de negros. Maiores considerações sobre a emergência e a consolidação do futebol em Pelotas e na região, consultar: RIGO, L. C. Memórias de um Futebol de Fronteira. Pelotas: Editora Universitária UFPel, 2004. (Coleção História e Etnias de Pelotas, v. 8).

${ }^{5}$ Michel Foucault (1979, p.143) destaca que se apropriar de um autor pressupões "[...] utilizá-lo, deformá-lo, fazê-lo ranger, gritar". Maiores considerações sobre, a teoria, o uso de autores e o conceito de caixa de ferramenta no pensamento de Michel Foucault, consultar Jódar e Gómez, 2004.
}

Novimento, Porto Alegre, v. 16, n. 03, p. 155-179, julho/setembro de 2010. 
entre "descrição" e "explicação" aqui aparece como sendo, de forma ainda mais relativa, entre "inscrição" ("descrição densa") e "especificação" ("diagnose") - entre anotar o significado que as ações sociais particulares têm para os atores cujas ações elas são e afirmar, tão explicitamente quanto nos for possível, o que o conhecimento assim atingido demonstra sobre a sociedade na qual é encontrado e, além disso, sobre a vida social como tal. (GEERTZ, 1989, p. 19)

Em parte foi isso que objetivamos fazer quando realizamos uma descrição cuidadosa do futebol de várzea e uma análise interpretativa da relevância e dos significados que ele possui para as classes populares, atentando para a premissa de que na análise interpretativa "[...] a tarefa essencial da construção teórica não é codificar regularidades abstratas, mas tornar possíveis descrições minuciosas; não generalizar através dos casos, mas generalizar dentro deles" (GEERTZ, 1989, p. 18).

Respeitando a singularidade de cada autor, utilizamos também algumas reflexões teóricas e metodológicas feitas por Loïc Wacquant (2002), principalmente o conceito de "Participação Observante", com o qual ele defende a importância da experimentação corpórea das práticas pesquisadas ${ }^{6}$.

A partir dessa postura teórica e metodológica acompanhamos e realizamos observações com registros escritos e fotográficos do Campeonato Citadino, edições 2006 e 2007, e do Campeonato Praiano, edição 2006/2007, em suas diferentes fases ${ }^{7}$.

Além dos jogos acompanhamos também as reuniões semanais

\footnotetext{
${ }^{6}$ Apesar de não termos participado dos jogos que foram analisados, todos os autores deste estudo possuem uma vivência significativa com a prática do futebol e também do futebol de várzea especificamente. Por sermos professores de Educação Física, em vários momentos do trabalho de campo, fomos consultados pelos diretores da LPFA sobre questões referente à arbitragem e a própria organização das competições que acompanhávamos.

${ }^{7} \mathrm{O}$ estudo abarca as edições de 2006 e 2007 do Campeonato Citadino porque, quando começamos a pesquisa em 2006, a competição já estava na fase semifinal; como queríamos ter registros de todas as fases, decidimos acompanhar também a edição de 2007.
} 
dos representantes dos clubes e as reuniões dos árbitros durante os dois anos (2006 e 2007); participamos das atividades festivas organizadas pela LPFA; e realizamos duas entrevistas semi-estruturadas - uma com o diretor de árbitros da LPFA (Gladimir Dias) ${ }^{8}$ e outra com o dirigente do Força Jovem Futebol Clube (Sérgio Rosa) ${ }^{9}$, clube tradicional da cidade que participou dos campeonatos que selecionamos para estudar. Essas entrevistas seguiram as indicações técnicas e metodológicas sugeridas por Triviños (1987). Por fim, simultaneamente ao trabalho de campo, fizemos uma análise dos documentos que estavam arquivados na LPFA, quando consultamos os regulamentos das competições, as fichas de inscrições dos times das diferentes categorias, as atas das reuniões da LPFA, as súmulas dos árbitros, etc.

A opção por utilizarmos também a fotografia como uma forma de registro e observação dos jogos deu-se por julgarmos que, através dela, seria possível analisar, com mais propriedade, características e rituais peculiares do futebol de várzea, como, por exemplo, a situação dos campos e as manifestações dos torcedores, antes, durante e depois das partidas. As fotografias foram utilizadas para o registro dos sentidos estéticos e histórico-culturais dos acontecimentos sociais (BARTHES, 1984), elas aparecem aqui como um enunciado imagético que, ao se entrelaçarem ao discurso escrito, formam um único texto, composto por imagens e palavras.

\section{Os CAMPEONATOS PRAIANO E CITADINO}

A LPFA foi fundada no dia 11 de dezembro de 1907, sendo reconhecida pela Federação Gaúcha de Futebol como a liga mais antiga do Estado, ainda em atividade ${ }^{10}$. Apesar de os três times profissionais da cidade (Grêmio Esportivo Brasil, Esporte Clube Pelotas

\footnotetext{
${ }^{8}$ DIAS, G. Entrevista com Gladimir Dias. Pelotas, 10 de maio de 2007. Entrevista concedida a Luciano Jahnecka e Inácio Crochemore M. da Silva.

${ }^{9}$ ROSA, S. Entrevista com Sérgio Rosa. Pelotas, 8 de dezembro de 2007. Entrevista concedida a Luciano Jahnecka e Luiz Carlos Rigo.

${ }^{10}$ Durante o ano de 2007 ocorreram várias homenagens alusivas ao centenário da LPFA, entre as quais se destacou a Audiência Pública que ocorreu na Câmara de Vereadores no dia 31/8/ 2007, quando houve o lançamento de um selo comemorativo ao centenário da liga.
} 
e Grêmio Atlético Farroupilha) pertencerem à Liga, nos últimos anos a entidade vem priorizando o futebol não-profissional ${ }^{11}$.

\subsection{O CITADINO}

O primeiro Campeonato Citadino organizado pela LPFA data de 1913, mas essa competição possuía uma configuração bastante distinta do Campeonato Citadino Varzeano atual. De acordo com as informações de Ivan Líneo Ziebell, presidente da LPFA na gestão 2006/2007 e membro de outras diretorias, o campeonato citadino nos moldes atuais começou a ser disputado a partir de 1980, mas, segundo ele, já nos anos 50 e 60 ocorriam competições similares envolvendo os clubes da cidade.

Atualmente o Campeonato Citadino começa no mês de maio e se estende até novembro, podendo participar os clubes que são filiados à LPFA e estão em dia com a entidade ${ }^{12}$. Nas edições de 2005, 2006 e 2007, além das tradicionais categorias de Primeiro e Segundo Quadro, também chamadas de Titulares e Reservas, a competição contemplou também as categorias Veteranos (ou Sênior, acima de 35 anos), Juvenil, Infanto e Mirim. O Primeiro e o Segundo Quadros são vinculados, o que impede que um clube inscreva uma equipe somente em uma dessas duas categorias. As outras categorias são independentes, o que possibilita que um clube inscreva uma equipe em qualquer uma das categorias.

\footnotetext{
${ }^{11}$ Além da LPFA, também existe em Pelotas a ACP (Associação Colonial de Pelotas), fundada em 1965; a ADCP (Associação Desportiva da Colônia de Pelotas), fundada em 1980; e a ACE (Associação Colonial Esportiva), fundada em 1994. Essas três entidades tratam especificamente do futebol que ocorre na zona rural da cidade (um desdobramento do futebol de várzea). ${ }^{12}$ No Campeonato Citadino de 2006, participaram os seguintes clubes: categoria Titular e Reservas - Família F. C., Santos F. C., S. R. Liberal, São Miguel F. C., S. E. R. Força Jovem, Fortaleza F. C., G. E. Flamengo, Bairro Simões Lopes F. C.; categoria Sênior, acima de 35 anos - Família F. C., Renegados F. C., Bairro Simões Lopes F. C., Fortaleza F. C., Roma F. C., Nacional F. C., Santos F. C., Rei F. C., Vasco Pires F. C., S. R. Liberal, Santa Cruz F. C., G. E. Flamengo; categoria Juvenil - Progresso F. C., G. A. Farroupilha, E. C. Pelotas, C. T. Princesa do Sul, Fortaleza F. C.; categoria Infanto - Progresso F. C., G. A. Farroupilha, E. C. Farias, E. C. Pelotas, C. T. Princesa do Sul, Galera F. C.; categoria Mirim - Progresso F. C., G. A. Farroupilha, E. C. Pelotas, C. T. Princesa do Sul, Galera F.C. (Fichas de inscrição dos clubes que participaram dos Campeonatos Citadinos de 2006. Arquivos da LPFA, Pelotas, 2007)
} 
Os Titulares e os Reservas jogam domingo à tarde, as outras categorias jogam sempre no sábado à tarde e no domingo pela manhã. Na primeira fase da competição, as equipes são agrupadas em chaves pelo critério de localização geográfica e jogam entre si no sistema de ida e volta (uma partida no campo de cada time). A maioria desses jogos ocorre em campos abertos, esburacados, sem marcações e sem vestiários ${ }^{13}$. Em toda a primeira fase, a arbitragem é feita somente pelo árbitro principal, sem árbitros auxiliares.

A partir da fase semifinal, os jogos passam a ocorrer em um único campo fechado, alugado pela LPFA. Diferente da primeira fase, esses jogos envolvem uma estrutura e uma organização um pouco maior. A arbitragem fica a cargo de um árbitro principal e de dois assistentes (bandeirinhas). Parte significativa da imprensa esportiva da cidade (rádios, jornais e emissoras de televisão locais) cobre o evento, principalmente as finais. Nas fases semifinal e final, começa a haver a cobrança de ingressos. Nos campeonatos de 2006 e 2007, na semifinal e na final o ingresso custava dois reais. A decisão sobre onde ocorrem essas duas fases fica a cargo da LPFA, que, como observou Gladimir, faz a escolha considerando vários fatores:

Primeiro era no Farroupilha, 'Estádio do Grêmio Atlético Farroupilha'. Aí o Farroupilha começou a ficar muito caro, muitas despesas pros clubes; aí a gente passou para o Parque do Trabalhador. Aí o Parque do Trabalhador não quis mais alugar, então se passou pro Progresso, se jogou sei lá quanto tempo no Progresso, e, agora, já é o terceiro ano que vem sendo no Bancário (DIAS, 2007).

\footnotetext{
${ }^{13} \mathrm{As}$ disputas nas categorias de base seguem outra metodologia; geralmente elas ocorrem em apenas um ou dois campos da cidade.
} 


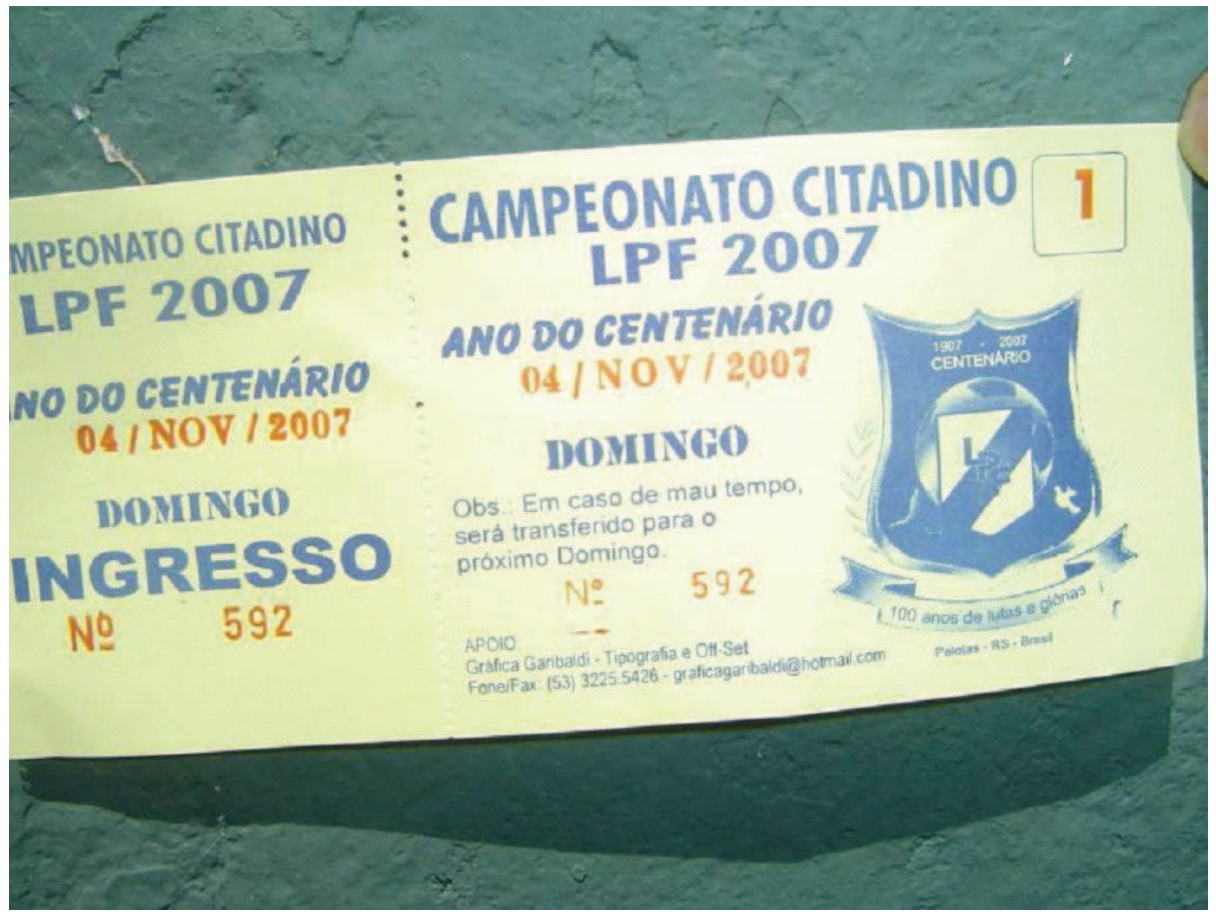

Figura 1: Os Ingressos para as partidas das semifinais e da final do Citadino de 2007 custavam dois reais e faziam uma homenagem ao Centenário da LPFA.

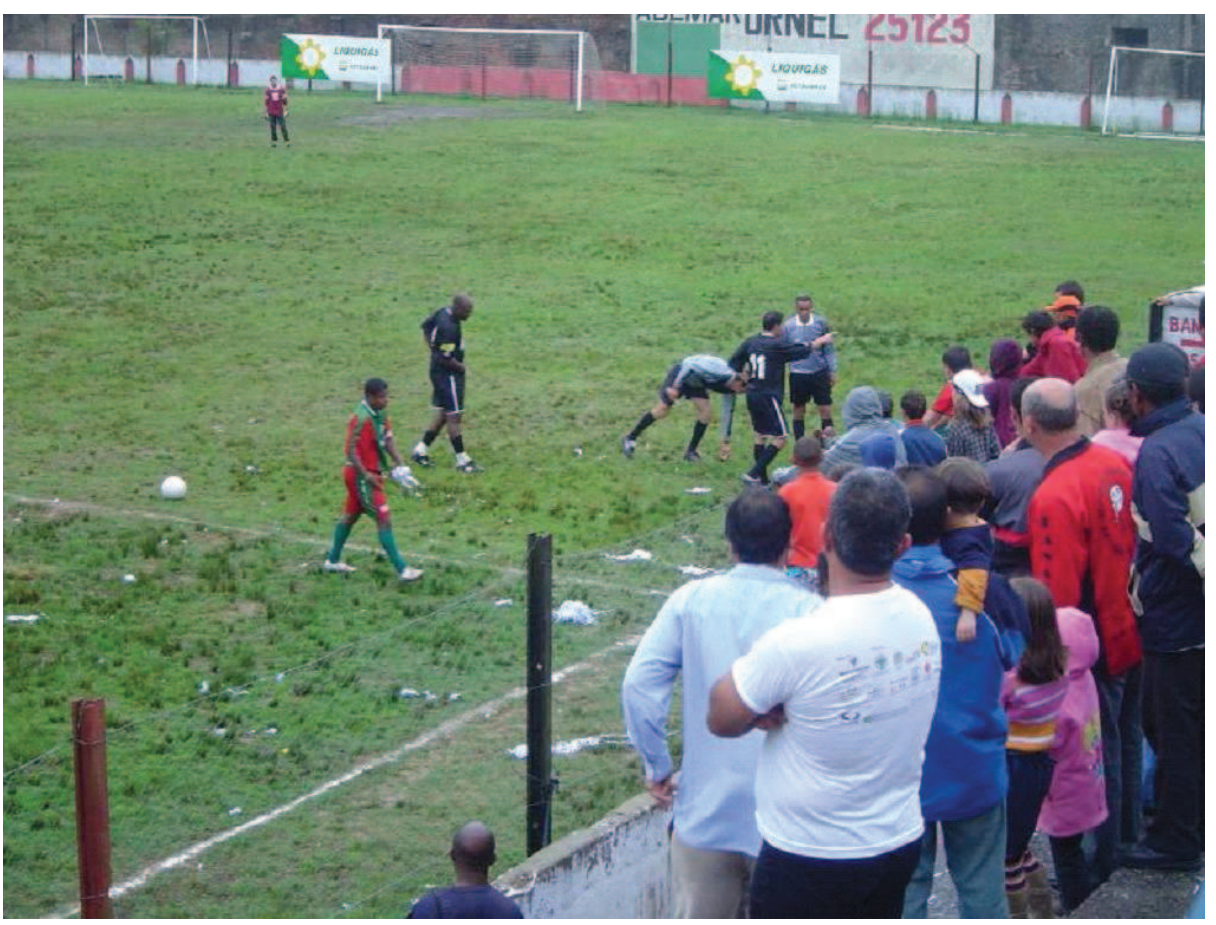

Figura 2: As semifinais e a final do Campeonato Citadino sempre ocorreram em campos fechados, com a presença de um árbitro principal e de dois árbitros auxiliares - bandeirinhas. (Final do Campeonato Citadino 2006, Segundo Quadro. Campo dos Bancários, Bairro Simões Lopes). 


\subsection{O PRAIANO}

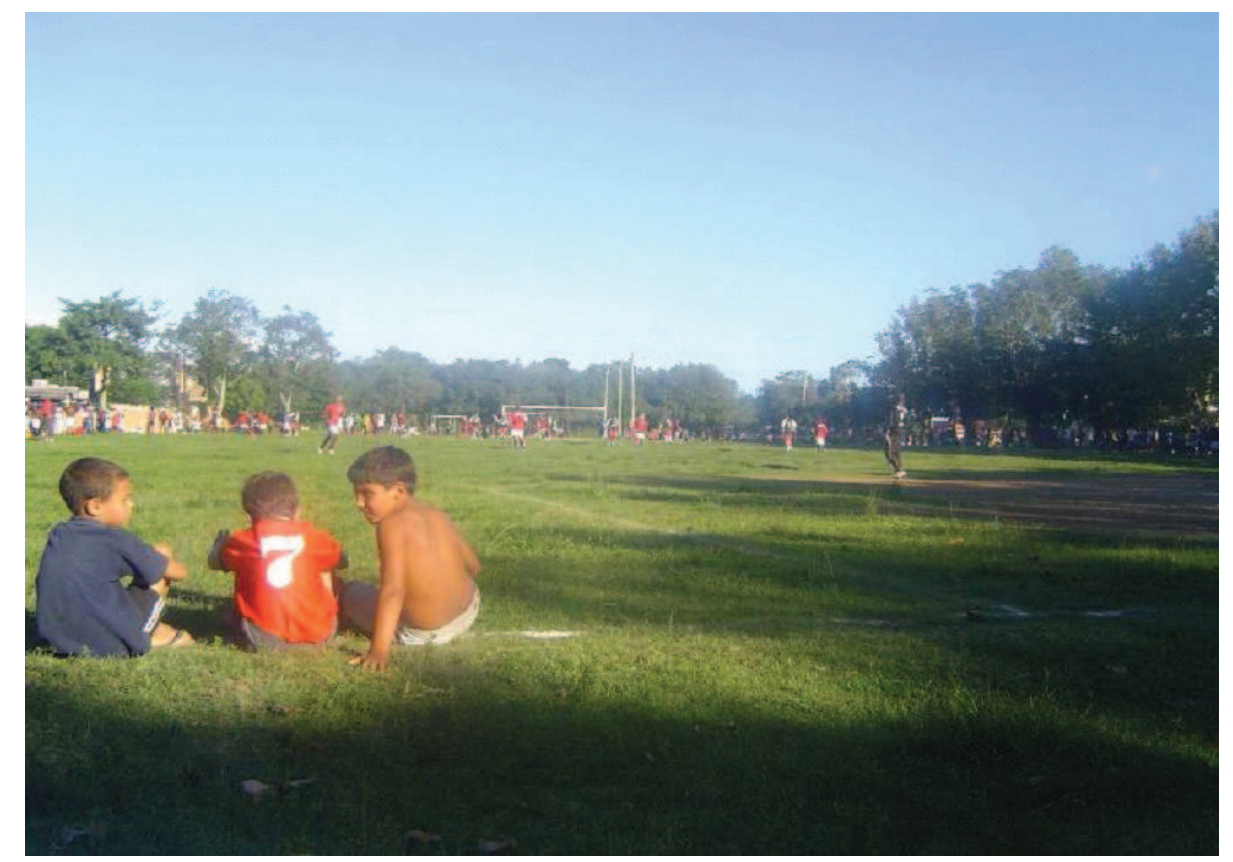

Figura 3: Os jogos dos adultos aproximam as crianças do universo do futebol varzeano, através deles as crianças vão conhecendo os times, os jogadores e vão familiarizando-se com as artimanhas desse futebol. (Campeonato Praiano 2006/2007, Campo da Praça Aratiba, Bairro Barro Duro).

O Campeonato Praiano ocorre no Balneário dos Prazeres, na praia do Laranjal. Inicialmente essa competição começou apenas com a categoria Sênior I (acima de 35 anos) e, mais tarde, foi ampliado também para as categorias de Titulares e de Sênior II ou Veteranos (com mais de 45 anos). A versão 2006/2007 desta competição representou a $5^{\text {a }}$ edição para Sênior I, a $9^{a}$ edição para a categoria Titulares e a $18^{\mathrm{a}}$ edição para a categoria Sênior I (arquivos da LPFA) ${ }^{14}$

Todos os jogos do Praiano ocorrem em um único campo aberto, de grama, que fica na Praça Aratiba, no bairro Barro Duro. Para

\footnotetext{
${ }^{14}$ No Campeonato Praiano de 2006/2007, participaram os seguintes clubes: categoria Titular Fortaleza F. C., G. E. Flamengo, A. E. N. S. Navegantes, Rei F. C., São Miguel F. C., Avaí F. C., Santa Cruz F. C., E. C. Tricolor, Santos F. C., F. C. B. N. Fátima, S. E. Aratiba, Centenário F. C., E. C. Ideal, S. E. R. Força Jovem, II Amigos F. C., Madureira F. C.; categoria Sênior acima de 35 anos - Barretos F. C., Rei F. C., Santa Cruz F. C., Renegados F. C., Roma F. C., U. E. Udinese, Avaí F. C., Nacional F. C., Centenário F. C., S. E. C. Juventus, A. E. N. S. Navegantes, G. E. Flamengo A, G. E. Flamengo B, Bairro Simões Lopes F. C.; categoria acima de 45 anos - Vasco Pires F. C., Portuguesa E. C., Trianon E. C., Bairro Simões Lopes F. C., U. E. Udinese, Nacional F. C., Osório F. C., Fortaleza F. C. (Fichas de inscrição dos clubes que participaram dos Campeonatos Praiano de 2006/2007. Arquivos da LPFA, Pelotas, 2007).
} 
ajudar a manter a torcida fora do campo durante os jogos é instalada uma corda entre as árvores que existem ao lado da linha lateral do campo a uma altura média de um metro. As partidas ocorrem aos sábados, domingos e feriados, de manhã e à tarde. $\mathrm{O}$ campeonato geralmente inicia na primeira quinzena de dezembro e estende-se até o final de fevereiro. Como a competição possui um período delimitado para a sua realização, a LPFA limitou em dezesseis o número máximo de equipes que podem inscrever-se em cada uma das categorias.

Por ser uma competição voltada para o futebol não-profissional, acordou-se que somente "na categoria de Titulares cada clube poderá inscrever um atleta que esteja atuando nos clubes profissionais" (Art. 30, Regulamento 2006/2007) ${ }^{15}$. As regras utilizadas nas três categorias são praticamente as mesmas do futebol profissional, apenas com alguns ajustes pontuais, como no caso das substituições, onde se estabeleceu que "será permitido fazer sete substituições em cada partida, em todas as categorias, sendo que na categoria de sênior e veterano o atleta substituído poderá retornar a campo só mais uma vez, devendo assinar a súmula novamente para que conte como nova substituição" (Art. 7º, Regulamento 2006/2007).

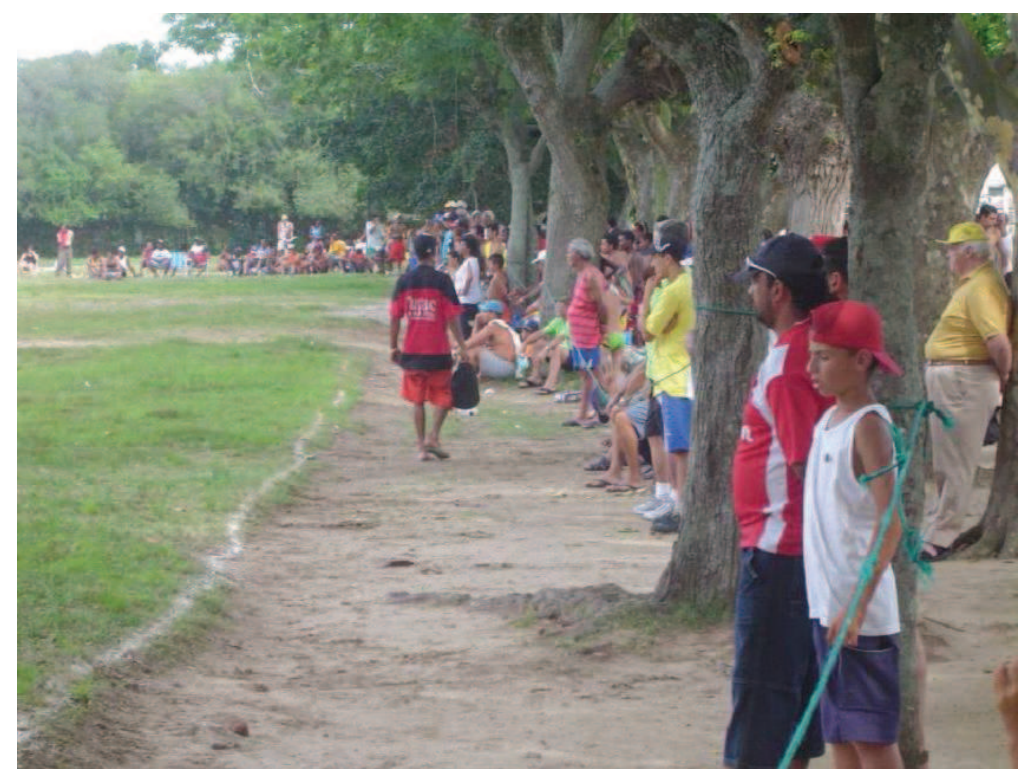

Figura 4: A corda ajuda a manter o público afastado da linha lateral do campo.

(Campo da Praça Aratiba, Bairro Barro Duro, local onde ocorreram todos os jogos do Praiano 2006/2007).

${ }^{15}$ Regulamento do Campeonato Praiano de 2006/2007. Arquivos da LPFA, Pelotas, 2007.

Wovimento, Porto Alegre, v. 16, n. 03, p. 155-179, julho/setembro de 2010. 


\section{SuJEITOS dA VÁRZEA}

\subsection{JOGADORES}

No levantamento que realizamos junto aos arquivos da LPFA, identificamos quantos e quais são os times e os jogadores que se envolveram nessas duas competições nos últimos cinco anos.

O Campeonato Praiano de 2006/2007, por exemplo, contou com dezesseis equipes inscritas na categoria principal (máximo aceito pela Liga), quatorze na categoria acima de 35 anos e oito na acima de 45 anos, totalizando 38 equipes na competição. Se considerarmos que, em média, cada equipe inscreve em torno de vinte jogadores, o campeonato teve cerca de 750 jogadores inscritos. Através dos registros das outras cinco edições do campeonato (2002/2003, 2003/2004, 2004/2005, 2005/2006 e 2006/2007), observamos que, com algumas alterações na categoria acima de 45 anos, o número de times manteve-se praticamente o mesmo. Esta regularidade mostra a tradição que essa competição alcançou junto ao futebol varzeano da cidade.

O Campeonato Citadino de 2006 contou com sessenta equipes inscritas, sendo: dezesseis no Primeiro Quadro (Titulares); dezesseis no Segundo Quadro (Reservas); doze na categoria acima de 35 anos; cinco no Juvenil; seis no Infanto; e cinco no Mirim; totalizando cerca de 1.200 jogadores inscritos.

Apesar de muitos clubes e jogadores disputarem as duas competições, elas apresentam certas singularidades. Enquanto no Praiano há um significativo número de equipes que são formadas prioritariamente para disputar o campeonato, no Citadino predominam clubes de maior tradição, como são, por exemplo, os clubes de bairros. Essa diferença ocorre, principalmente, pelo Praiano ser uma competição que dura menos tempo que o Citadino e exige uma menor organização e estrutura das equipes, como observou o diretor de arbitragem da LPFA:

[...] na cidade não entram muito mais clubes porque a despesa é grande, deslocamento de uma zona para

Wovimento, Porto Alegre, v. 16, n. 03, p. 155-179, julho/setembro de 2010. 
outra, então se torna muito caro. [...] a praia não dá despesa. $\mathrm{O}$ clube vai lá jogar e bota um ônibus. $\mathrm{O}$ pessoal vai pra ver o time e vai pra se divertir, então ele lota um ônibus (DIAS, 2007).

Através das observações dos jogos e da análise das fichas dos jogadores, identificamos que a maioria dos sujeitos que disputam as duas competições são jogadores-trabalhadores que pertencem às classes populares e participam das competições exclusivamente por lazer ${ }^{16}$.

No geral poderíamos classificar os jogadores em dois grupos: os jogadores/dirigentes e os que são somente jogadores. Os primeiros caracterizam-se por mesclarem o papel de jogador com o de diretor do clube onde atuam. Eles permanecem no mesmo clube vários anos e estabelecem com ele um forte sentimento clubista. Os do segundo grupo se diferem desses por manterem um distanciamento maior com os clubes em que jogam. Para esses, o mais importante é jogar e disputar os campeonatos. Rodar, mudar de time, é normal, alguns jogam o Citadino por uma equipe e o Praiano por outra ${ }^{17}$.

\subsection{ARBITRAgEM}

No sábado de tarde: Fábio no primeiro jogo, nos de 45 está o Gildo e o Érico. No Domingo de manhã o Cláudio no primeiro jogo e o Clóvis no segundo. Nos Titulares o Fernando está no primeiro, o Cláudio no segundo e o Joca no jogo de fundo. (DIAS, Reunião dos árbitros, 12/01/07) ${ }^{18}$.

A passagem acima mostra o diretor de árbitros da LPFA, Gladimir Dias, em uma reunião, fazendo a escala da arbitragem para

\footnotetext{
${ }^{16}$ Através das conversas que tivemos com diretores de clubes, eles nos disseram que, apesar de não ser proibido, é muito difícil algum clube remunerar algum jogador para participar do Citadino ou do Praiano, como ocorre, por exemplo, no Futebol Colonial.

${ }^{17} \mathrm{Em}$ uma análise que fizemos sobre os jogadores e os times que disputaram as edições de 2002 a 2007 do Citadino, identificamos que cerca de $60 \%$ dos jogadores permaneceram nos mesmos clubes ao longo dessas oito competições.

${ }^{18}$ Reunião dos árbitros. Gravação. Pelotas, 12 de janeiro de 2007. Participação de Luiz Carlos Rigo, Luciano Jahnecka, Inácio Crochemore M. da Silva.
} 
a próxima rodada do Praiano 2006/2007. Durante as competições, essas reuniões são semanais, duram em torno de duas horas e ocorrem à noite na sede da Liga. As reuniões são coordenadas pelo diretor de árbitros e, além da equipe de arbitragem envolvida na competição, também participam delas outros diretores da Liga e convidados. Não é permitida a presença de representantes dos clubes ${ }^{19}$.

Durante a fase classificatória das duas competições as características da arbitragem são bastante similares e a maioria dos árbitros atua nos dois campeonatos. Nas duas competições os jogos ocorrem em um campo aberto, sem a presença da Brigada Militar, e o jogo é arbitrado somente pelo árbitro principal, que é responsável por assinalar desde arremessos laterais até impedimentos.

De acordo com Gladimir Dias (2007) um árbitro recebia sessenta reais por jogo na categoria Titular e cinqüenta reais nas demais. Segundo ele, após a primeira fase, "quando entra nas oitavas-de-final, que é jogo mata-mata, o valor aumenta um pouco". Esse valor era o mesmo para os dois campeonatos.

Para os árbitros a arbitragem é uma importante fonte de renda, quase uma segunda profissão. Ciente disso o diretor de árbitro cuida para não privilegiar ninguém. Após concluir uma das escalações de árbitros, Gladimir salientou: "Osvaldo, tu e o Fernando, vamos ver se no outro fim de semana eu encaixo dois jogos para vocês, pra não ficarem no prejuízo, já que todos os outros pegaram dois agora" (DIAS, Reunião dos árbitros, 12/01/2007).

Com a experiência e o conhecimento adquirido no próprio ofício, os árbitros vão desenvolvendo uma série de artimanhas e

\footnotetext{
${ }^{19} \mathrm{Além}$ das reuniões dos árbitros, durante as competições ocorrem também as reuniões com os representantes dos clubes. Elas são coordenadas pelo presidente da LPFA e delas participam os demais diretores e representantes dos clubes envolvidos na competição, que possuam direito de voz e de voto. As reuniões dos árbitros e as reuniões com os representantes dos clubes são os dois espaços nos quais são deliberadas as principais decisões referentes à organização e ao andamento das competições que a entidade promove.
} 
estratégias que os capacita a enfrentar os xingamentos, as ameaças, as invasões de campo e até mesmo alguma agressão física que, às vezes, acontece. Um bom exemplo dessas artimanhas é o posicionamento utilizado por eles nos campos abertos. Para evitar uma maior exposição com os torcedores que estão ao lado do gramado, eles apitam os jogos evitando as laterais, deslocando-se prioritariamente pela parte central do campo.

A falta de uma distância mínima entre os árbitros e os torcedores é um dos motivos pelos quais não se utiliza árbitros assistentes nos jogos em campos abertos. Segundo Gladimir, a LPFA fez a experiência de incluir árbitros assistentes em um Campeonato Praiano, mas não deu certo.

Um dos problemas mais freqüentes enfrentados pela arbitragem são as invasões de campo. Apesar de o regimento prever uma multa de vinte reais por invasão, nas reuniões de árbitros quase sempre há um caso de invasão em pauta. Os árbitros ficam com dúvidas sobre como proceder. Em uma reunião de árbitros, o diretor de arbitragem chamou a atenção para isso, salientando: "se invadiu, vocês vão ter que expulsar. Isso é cem por cento, invadiu sem a autorização do árbitro, tem que expulsar" (DIAS, Reunião dos árbitros, 12/ 01/2007).

Considera-se uma invasão quando uma ou mais pessoas entram no campo e atrapalham o jogo, agridem ou tentam agredir alguém. O simples ato de adentrar alguns metros o campo para acompanhar uma jogada mais distante ou para comemorar um gol junto com os jogadores, por exemplo, é uma prática corriqueira e está longe de ser considerado uma invasão. 


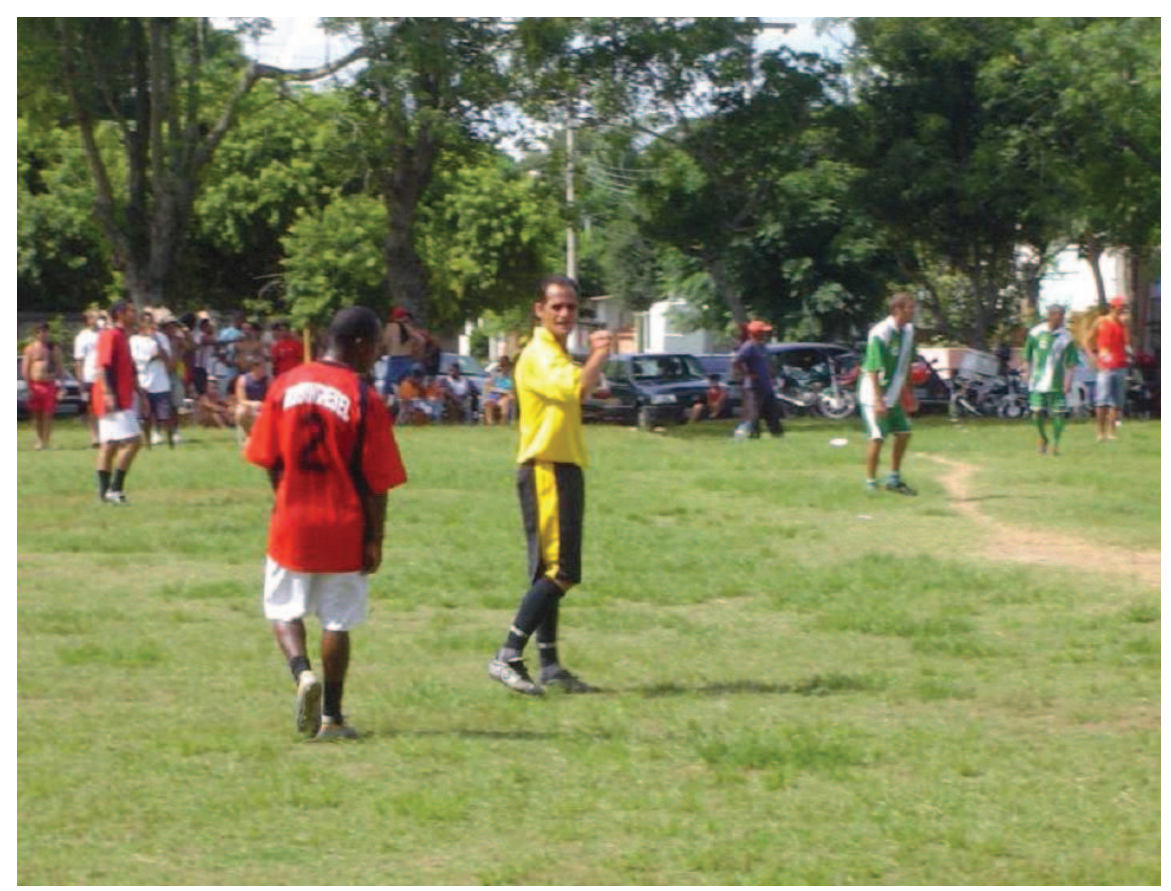

Figura 5: Sem os árbitros auxiliares, o árbitro principal costuma manter-se na linha central do campo. Esta estratégia de arbitragem, típica do futebol de várzea, além de possibilitar uma melhor visibilidade do jogo também deixa o árbitro menos exposto às pressões e às ameaças dos torcedores que estão nas laterais do campo. (Praiano 2006/2007, Campo da Praça Aratiba, Bairro Barro Duro).

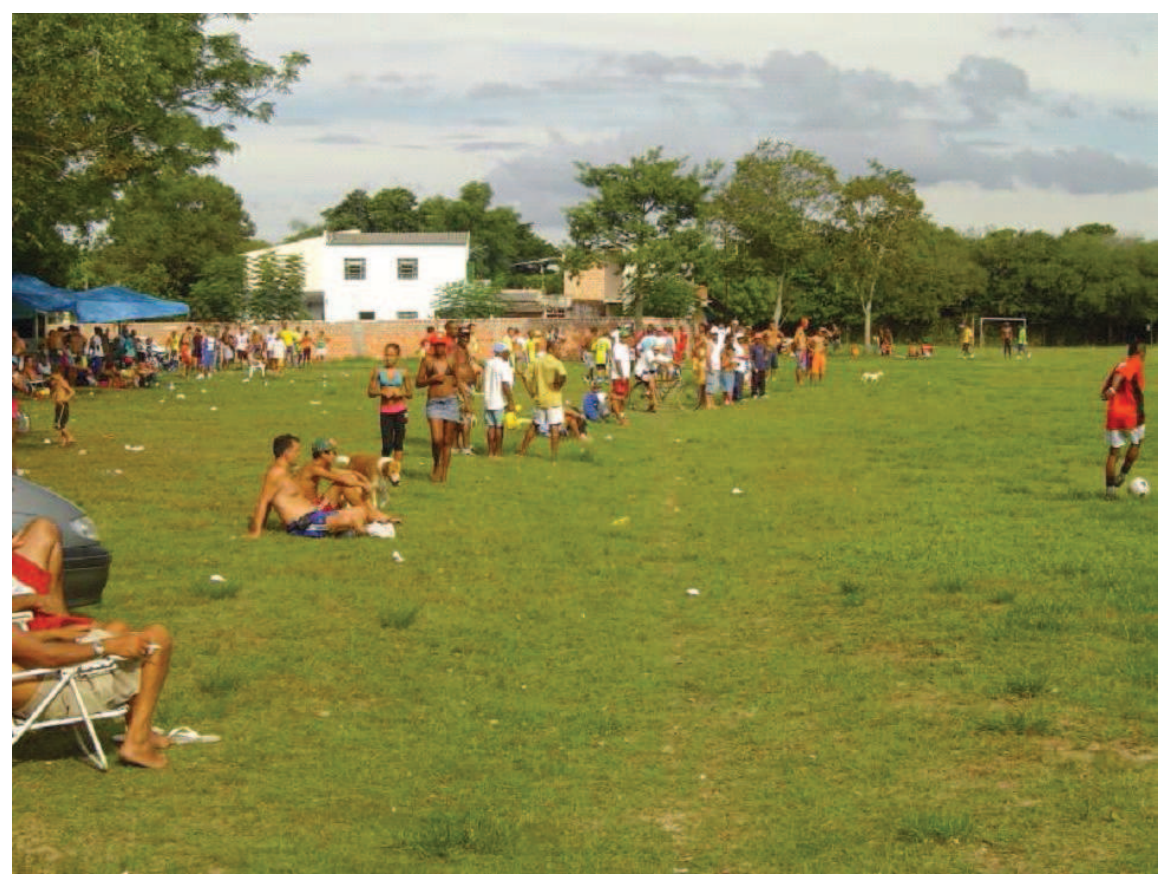

Figura 6: Em campos abertos - desde que não atrapalhe o jogo - é comum "invadir" o campo para acompanhar a partida. (Campeonato Praiano 2006/2007, Campo da Praça Aratiba, Balneário Barro Duro).

Movimento, Porto Alegre, v. 16, n. 03, p. 155-179, julho/setembro de 2010. 


\subsection{TORCEDORES E PÓS-TORCEDORES}

Eles vão de bicicleta, a pé, tu viu o número grande de gente, foi quase todo mundo a pé, ou de bicicleta, é pertinho. Quando é longe a gente coloca ônibus. (Sérgio Rosa, 08/12/2007).

A presença de público é uma constante nas duas competições. Enquanto no Praiano ela é mais regular do começo ao fim, no Citadino ela é maior na semifinal e na final e difere de um jogo para outro, de acordo com os times envolvidos. Os clubes de maior torcida são aqueles que possuem vínculos mais orgânicos com a comunidade a qual pertencem. Como comentou Sérgio Rosa (Serginho), os torcedores do SER Força Jovem, do qual é técnico, "são todos de dentro do bairro mesmo".

Quando o jogo é no bairro do clube (Bairro Sanga Funda) ou próximo a ele, os torcedores vão por conta própria, mas, se ele for um pouco mais distante, os clubes com maiores torcidas organizam pequenas excursões até o local. Na entrevista que realizamos com Serginho, ele comentou:

Sabes como nós organizamos? É assim. Tem um senhor que tem um ônibus, eu contrato o ônibus e aí eu tenho que ver quantos passageiros cabem sentados e em pé. Aqui dentro da cidade tem que ir em pé também. E então saio a vender as passagens: ó, pessoal, quem é que vai no jogo, coloco uma placa ali com excursão pra tal ou tal lugar (ROSA, 2007).

O público que participa do futebol de várzea pelotense possui uma grande diversidade. Apesar de os adeptos desse futebol pertencerem, predominantemente, às classes populares (baixa e média-baixa) eles apresentam uma significativa diferença quanto ao sexo, à idade, às etnias, bem como quanto aos interesses que os levam aos campos, principalmente quando não há cobrança de in$\operatorname{gresso}^{20}$.

\footnotetext{
${ }^{20}$ Esta diversidade é ampliada (e pode ser visualizada, por exemplo, nas figuras 7, 8 e 9) quando consideramos como adeptos do futebol de várzea também os torcedores, e não apenas os jogadores e os dirigentes dos clubes e da LPFA, onde predominam adultos do sexo masculino.
} 
Após acompanhar diversos jogos em vários campos da cidade, percebemos que, além dos clássicos torcedores que vibram e sofrem com os resultados dos seus times, há um grande número de pessoas que vão aos jogos sem estarem interessadas em torcer, no sentido mais tradicional desse termo, por nenhum dos times. Por não ter um sentimento clubista com as equipes que estão jogando, algumas pessoas mais assistem aos jogos do que torcem. Assim, apropriando-se de um conceito que Richard Giulianotti (2002) utiliza para classificar o público que vai ao futebol profissional, podemos dizer que esses sujeitos estariam próximos daquilo que o autor nomeou como "pós-torcedor", ou seja, eles são semi-especialistas no assunto, mais do que torcer, eles possuem um interesse estético pelo futebol.

Há também um grande número de pessoas (provavelmente a maioria) que participam dos acontecimentos desse futebol com outros interesses. Observando os jogos, identificamos que muitas pessoas que estão em torno do campo estão pouco atentas ao jogo. Para eles, os jogos de finais de semana são, prioritariamente, espaços de sociabilidade, momentos para encontrar a turma, conversar, paquerar, fazer novas amizades e se divertir.

Essa possibilidade de os campos de futebol de várzea funcionarem como um palco para o lazer e a sociabilidade, que aglutina jogadores, torcedores, pós-torcedores e outros, apesar de ser mais evidente no Campeonato Praiano ocorre nas duas competições. O lugar onde ocorrem os jogos do Praiano (uma praça arborizada próxima a uma praia) contribui para isso. Nos dois campeonatos, observamos que muitos assistentes levam para os arredores do campo, cadeiras, lanches, bebidas e o tradicional chimarrão. 


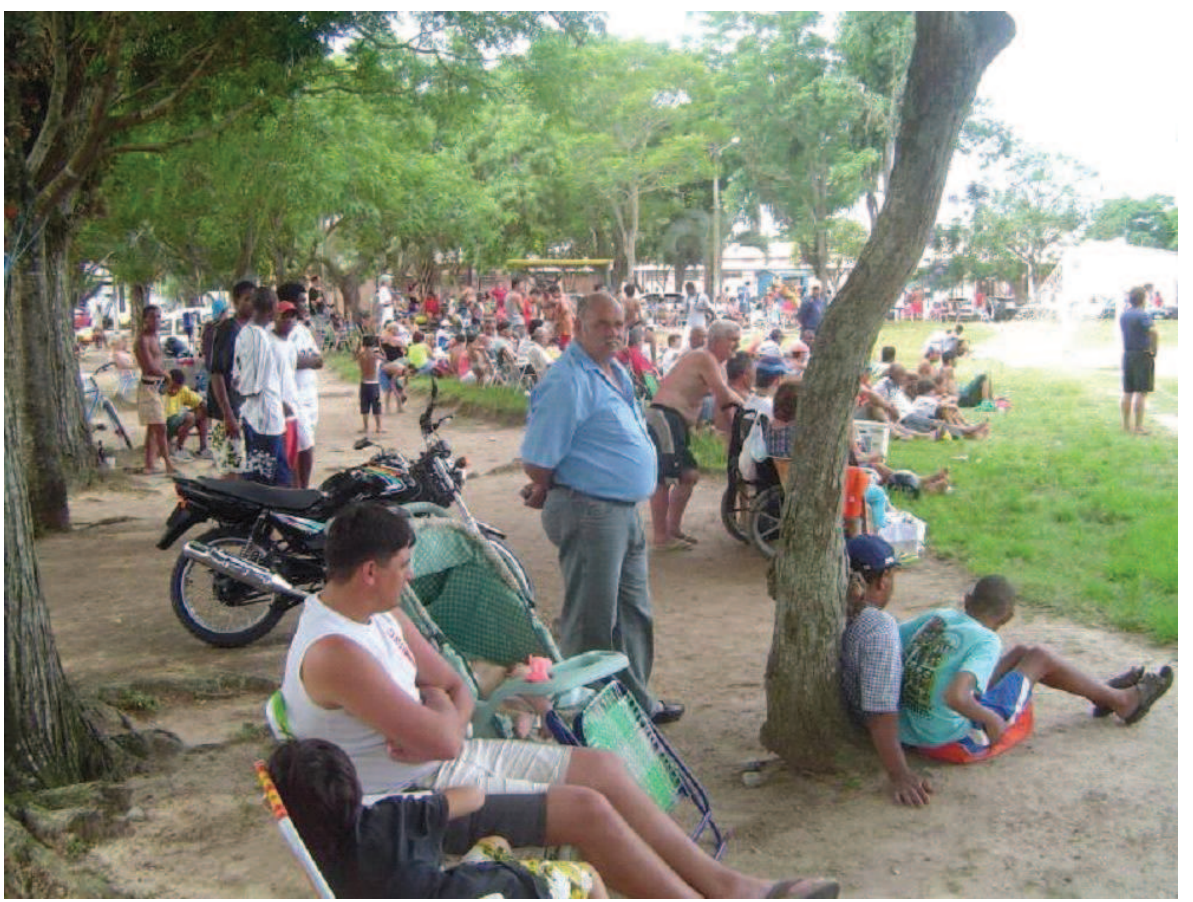

Figura 7: $\mathrm{O}$ aconchego do lugar ajuda a transformar os jogos do Campeonato Praiano em uma oportunidade para encontrar amigos, conversar, se divertir e olhar futebol. (Campeonato Praiano, 2006/2007, Campo da Praça Aratiba, Bairro Barro Duro).

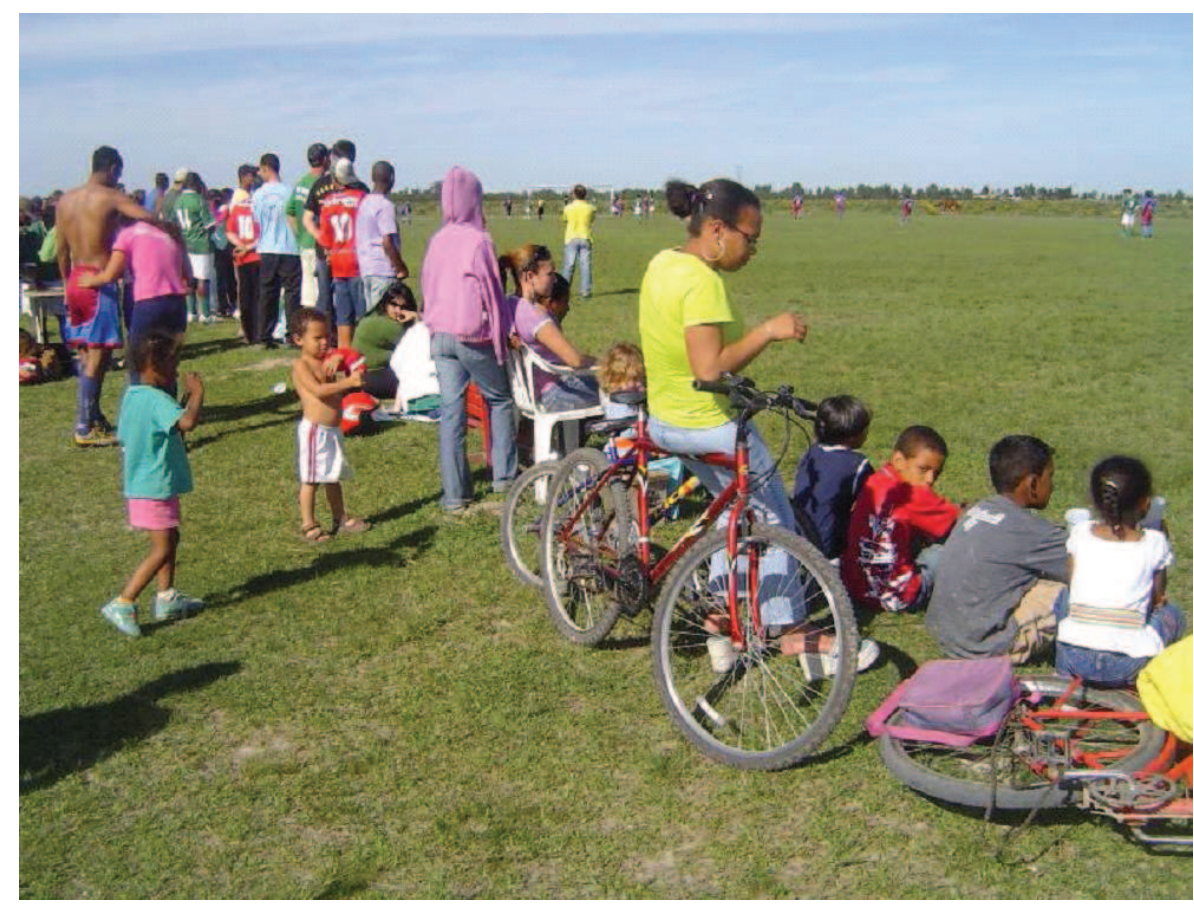

Figura 8: No Campeonato Citadino um grande público também prestigia os jogos desde a primeira fase, principalmente quando eles envolvem equipes que possuem fortes vínculos comunitários. (Campeonato Citadino, 2007, Jogo Cohab II X Força Jovem. Campo do Bairro Cohab II)

Wovimento, Porto Alegre, v. 16, n. 03, p. 155-179, julho/setembro de 2010. 


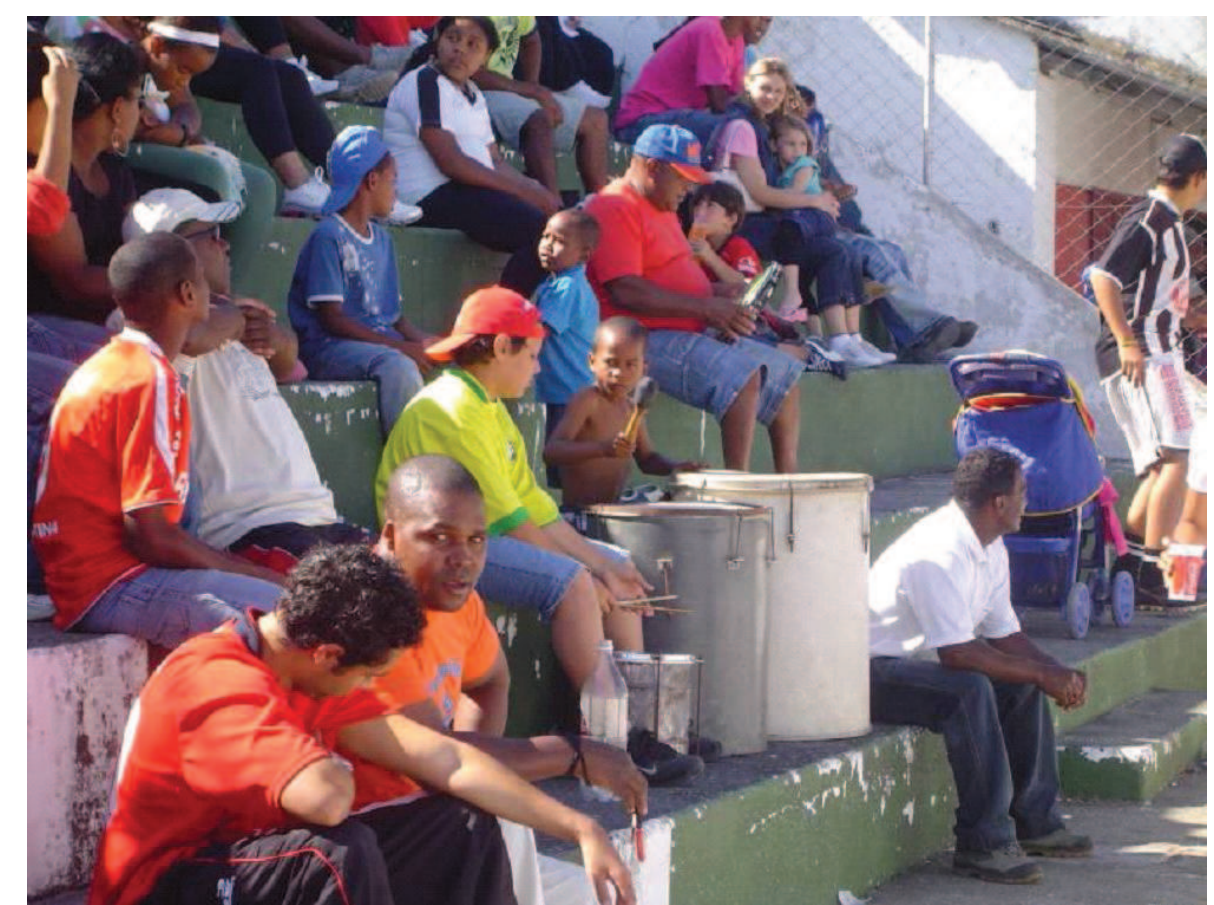

Figura 9: Na fase Semifinal e Final do Citadino os jogos ocorrem em um campo fechado com venda de ingresso, mesmo assim um grande público se faz presente, inclusive mulheres e crianças. (Final do Citadino 2007, Estádio do G. A. Farroupilha, Bairro Fragata).

\section{ConsideraçõEs finAS}

Dando seqüência aos preparativos para a próxima rodada da semifinal, Seu Ivan (presidente da Liga), que coordenava a reunião, distribuiu 80 ingressos para cada clube que iria jogar. Aproveitei a oportunidade e perguntei ao Serginho, técnico do Força Jovem, que estava sentado ao meu lado, o que ele iria fazer com os ingressos. Ele me respondeu que iria distribuir entre os jogadores, dirigentes e torcedores e salientou que 80 eram poucos. (Nota do diário de campo da reunião com os representantes de clubes em 06/11/2007) ${ }^{21}$.

Em Pelotas, o futebol varzeano, representado aqui pelo Praiano e pelo Citadino, constitui-se em um espaço público de lazer e de sociabilidade que mobiliza centenas de sujeitos de diferentes sexos,

\footnotetext{
${ }^{21}$ Diário de campo. Diário de campo das reuniões com os representantes de clubes, das reuniões dos árbitros e dos jogos do Campeonato Citadino e Praiano de 2006 e 2007. Anotações de Luiz Carlos Rigo; Inácio Crochemore M. da Silva; Luciano Jahnecka.
}

Wovimento, Porto Alegre, v. 16, n. 03, p. 155-179, julho/setembro de 2010. 
idades e etnias, fazendo com que os campos da várzea tornem-se "espaços multiuso", lugares "de lazer e recreação das crianças e adolescentes, do chimarrão e das fofocas" (DAMO, 2003, p.149). A presença feminina ao redor dos campos, nas torcidas organizadas, nas diretorias de alguns clubes e participando de alguns jogos festivos de futebol feminino ${ }^{22}$, mesmo ainda tímida, indica que aos poucos o futebol de várzea está deixando de ser uma "área masculina reservada" (DUNNING, 1992).

O espetáculo da várzea, como qualquer outro espetáculo esportivo, possui uma dimensão econômica que envolve o pagamento dos árbitros, a cobrança de ingressos, a anuidade que os clubes pagam à LPFA, as sanções e multas previstas no regulamento, as excursões e toda a movimentação financeira produzida pela copa ${ }^{23}$ nos dias de jogos. Os valores desta microeconomia - dois reais para o ingresso nas finais, sessenta reais para apitar uma partida, vinte reais de multa por invasão de campo - revelam e são condizentes com a classe social dos sujeitos que participam do espetáculo da várzea.

Quanto à violência, observamos que apesar das ameaças e das provocações verbais serem uma constante dentro de campo e nos arredores, durante os dois campeonatos que acompanhamos não presenciamos nenhuma agressão física. Acompanhamos muitas ameaças e algumas tentativas de agressões, direcionada à arbitragem, mas seus autores sempre foram contidos antes de implementá-las. Neste sentido, reconhecendo a complexidade desse assunto, arriscaríamos dizer que não raramente o futebol de Várzea é rotulado de violento. Nesse caso, como bem alertou Michel Maffessoli (1987, p. 15), generaliza-se o termo violência e ele

\footnotetext{
${ }^{22}$ Apesar de a cidade possuir uma tradição no futebol feminino, principalmente pelo trabalho desenvolvido pelo Esporte Clube Pelotas, que nos últimos anos participou do Campeonato Estadual de futebol feminino e revelou jogadoras para a Seleção Brasileira, A LPFA não organiza nenhuma competição (torneio ou campeonato) de futebol feminino. Maiores considerações sobre a tradição do futebol feminino na cidade podem ser encontrada no artigo "Notas acerca do futebol feminino pelotense em 1950: um estudo genealógico", RIGO et al. (2008). ${ }^{23} \mathrm{Copa}$ é a terminologia utilizada para denominar o local próximo ao campo onde, em dia de jogo, ocorre a venda de bebidas, lanches, etc. Ela representa uma das fontes financeiras que os clubes possuem para a sua manutenção.
} 
torna-se apenas "uma maneira cômoda de reunir tudo o que se refere à luta, ao combate, ou seja, à parte sombria que sempre atormenta o corpo individual e social"24.

Enfim, semelhante ao que assinalou Bauler (2005) sobre o futebol de várzea de Porto Alegre, Hirata (2005) e Spaggiari (2008) sobre a situação dele em São Paulo, concluímos que em Pelotas também o futebol de várzea continua sendo uma prática esportiva de lazer das classes populares. Apesar da pouca atenção que costuma receber dos órgãos governamentais e das políticas públicas oficiais, ele se mantém vivo e pode ser caracterizado como uma opção de lazer e sociabilidade que se contrapõem às práticas individualistas e segregacionistas que apontam para a desqualificação dos espaços públicos de sociabilidade (SENNET, 1998). Como observou Arlei Damo (2003, p. 150) no futebol de várzea "prevalece o gosto pela sociabilidade coletiva". Para compreender o valor dessas práticas, é necessário perceber que elas são:

[...] modalidades simples e tradicionais, que não têm o brilho e a sofisticação das últimas novidades da indústria do lazer, nem apresentam conotações políticas ou de classe explícitas, mas estão profundamente vinculadas ao modo de vida e às tradições dessa população. (SANTOS, 1999, p. 117).

Assim, diferente dos discursos fatalistas que falam de um possível fim do futebol de várzea, alguns estudos atuais que se utilizam de dados empíricos mostram que ele está longe de desaparecer ${ }^{25}$. Mesmo sem ter "conservado o romantismo do passado a várzea

\footnotetext{
${ }^{24} \mathrm{Apesar}$ da demanda social que existe sobre o tema da violência, optamos por não priorizá-lo neste estudo. Consideramos que a violência e outros temas como, por exemplo, os vínculos políticos de dirigentes dos clubes e das ligas de futebol, as diferentes estratégias de sustentabilidade utilizadas por inúmeros clubes de várzea são exemplos de eixos-temáticos que possuem relevância e são merecedores de outras investigações.

${ }^{25}$ Outro trabalho recente que faz referência ao futebol de várzea é o artigo de Edmilson Santos: "A representação dos campos de várzea na cidade: um espaço de memória". História: Questões \& Debates, Curitiba, n. 47, p. 203-211, 2007. Diferente dos discursos que apenas lamentam o desaparecimento do futebol de várzea, o autor trata do lugar que esse futebol ocupa no imaginário dos futebolistas e na memória esportiva da cidade. Porém, assim como outros autores, Santos também parece compartilha da hipótese que aponta para um desaparecimento do futebol de várzea, concluindo que "a várzea já não representa o futebol, o futebol já não representa o esporte na cidade e o esporte na cidade já não representa mais a memória esportiva de seus antigos praticantes" (SANTOS, 2007, p. 211).
} 
existiu, existe e talvez não morra nunca" (ADAUTO, 1999, p.127), principalmente porque ela é "acima de tudo, um estado de espírito" (WITTER, 1982, p. 102).

$\mathrm{Na}$ cidade de Pelotas especificamente, ao invés do seu desaparecimento, diagnosticamos que o futebol de várzea ampliou suas categorias, deslocou-se para a praia, para a periferia e para a zona rural, onde produziu um organizado Futebol Colonial ${ }^{26}$. Reinventado, o futebol de várzea dura o ano inteiro e é um importante acontecimento de lazer das classes populares. Além de movimentar uma significativa microeconomia ele continua a formar jogadores para o Futebol Profissional27.

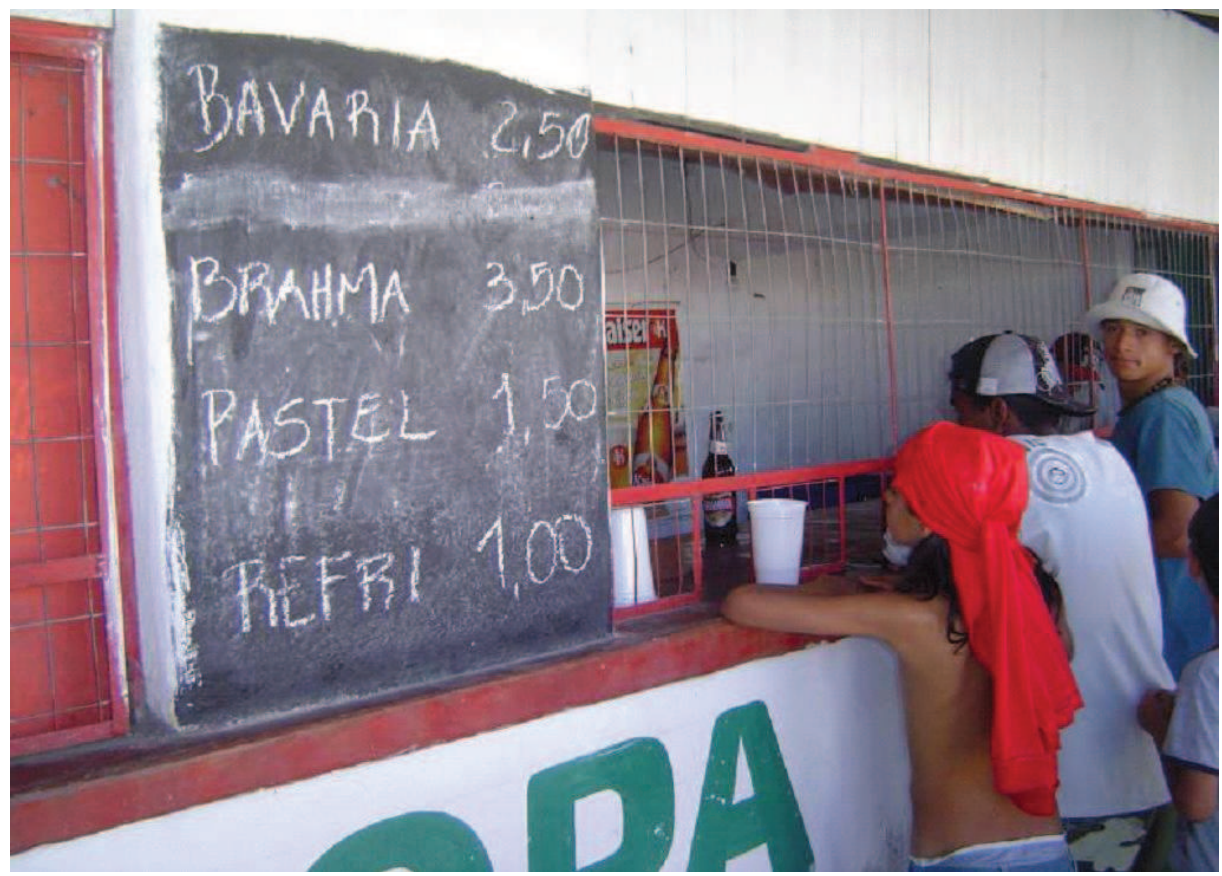

Figura 10: A tradicional Copa é um elemento estratégico da microeconomia que ajuda a manter o futebol de várzea. (Final do Campeonato Citadino 2007, Estádio do Grêmio Atlético Farroupilha, Bairro Fragata).

\footnotetext{
${ }^{26}$ Esse futebol que ocorre na zona rural, é uma variação do clássico Futebol de Várzea. Em Pelotas, muitos são os clubes que participam do Futebol Colonial em uma das três ligas existentes: ACP, ADCP, ACE. Como um exemplo da organização desse futebol, podemos citar o caso da ACP (Associação Colonial de Pelotas), que tem a sua sede no centro da cidade e possui um site (www.acpfutebol.com.br), pelo qual é possível acompanhar detalhes do campeonato que ela organiza anualmente no segundo semestre.

${ }^{27}$ Vários são os casos de jogadores que passaram pelo Futebol de Várzea de Pelotas antes de se tornarem profissionais. Exemplos disso é o caso do Emerson (Emerson Ferreira da Rosa), ex-volante da Seleção Brasileira que atua no futebol Europeu, e do Taison (Taison Barcellos Freda), jogador do Internacional de Porto Alegre, revelação do Campeonato Estadual de 2009. Emerson e Taison jogaram nas categorias de base do Progresso F.C. (Clube Amador de Pelotas) e transitaram pelo Futebol Varzeano da cidade.
} 


Ethnographic notes about the communitarian
soccer
Abstract : This study aims to describe and analyze
the current state of communitarian soccer
(neighborhood amanteur soccer) in Pelotas, Brazil.
Through a interpretative ethnography, observations
(notes and photos), semi-structured interviews and
the analysis of documents, a careful study about the
beach and city championships, the two main
competitions in the Pelotense amateur soccer league
(LPFA), was carried out. It was concluded that in
Pelotas, communitarian soccer is far from getting to
an end. Reinvented, it continues to be one of the main
leisure practices of the city working classes.
Keywords: Soccer. Leisure Activities. Socialization.

Notas etnograficas sobre el fútbol comunitario Resumen: Este estudio tiene como objetivo describir y analizar el estado actual del fútbol comunitario (fútbol amador, de barrio) en la ciudad de Pelotas, Brasil. A través de la etnografía interpretativa, por medio de observaciones participantes (registros escritos y fotográficos), entrevistas semi-estructuradas y el análisis de documentos escritos, se realizó un estudio cuidadoso del Campeonato Playero y el Campeonato Citadino. Que son las dos principales competiciones organizadas por la Liga Pelotense de Fútbol Amador (LPFA). Concluimos que en la cuidad de Pelotas el fútbol comunitario será difícil de acabar. Reinventado, ello continuará siendo una de las principales prácticas de interés deportivo de las clases trabajadoras de la ciudad.

Palabras-clave: Fútbol. Actividades Recreativas. Socialización.

\section{REFERÊNCIAS}

ADAUTO, F. Ainda se joga futebol na Cidade com muito amor. In: DA COSTA, M. Regina (Org.). Futebol: espetáculo do século. São Paulo: Musa, 1999. p. 122- 127.

BARTHES, R. A câmara clara: nota sobre a fotografia. Tradução: Júlio Castañon Guimarães. Rio de Janeiro: Nova Fronteira, 1984.

BAULER, S. R. G. O futebol faz rolar mais do que uma bola: um estudo sobre o significado do futebol numa periferia urbana. Dissertação de Mestrado, Universi- 
dade Federal do Rio Grande do Sul, Programa de pós-graduação em Educação Física, Porto Alegre, 2005.

DAMO, A. S. Monopólio estético e diversidade configuracional no futebol brasileiro. Movimento, Porto Alegre, v. 9, n. 2, p. 129-156, maio/ago., 2003.

Do Dom a Profissão: formação de futebolistas no Brasil e na França. São Paulo: Aderaldo \& Rothschild; Anpocs, 2007.

DUNNING, E. O desporto como uma área de masculinidade reservada: notas sobre os fundamentos sociais na identidade masculina e as suas transformações. In: ELIAS, N.; DUNNING, E. (Org.). A busca da excitação. Lisboa, Portugal: Difel, 1992.

FOUCAULT, M. Sobre a prisão. In: Microfísica do poder. Rio de Janeiro: Edições Graal, 1979. p. 129-144.

JÓDAR, F.; GÓMEZ L. Experimentar o presente: sobre a conformação de novas identidades. Educação \& Realidade: Dossiê Michel Foucault. Porto Alegre, v. 29, n. 1, p. 139-153, jan./jun., 2004.

GEERTZ, C. Nova luz sobre a antropologia. Rio de Janeiro: Jorge Zahar, 2000.

A interpretação das culturas. Rio de Janeiro: LTC, 1989.

HIRATA, D. V. O futebol varzeano: práticas sociais e disputas pelo espaço em São Paulo. Dissertação de Mestrado, Universidade de São Paulo, Programa de pós-graduação em sociologia, Faculdade de Filosofia, Letras e Ciências Humanas. SP, 2005.

GIULIANOTTI, R. Sociologia do futebol: dimensões históricas e socioculturais do esporte das multidões. São Paulo: Nova Alexandria, 2002.

MAFESSOLI, M. Dinâmica da Violência. São Paulo: Revista dos Tribunais, 1987.

MURAD, M. Dos Pés à Cabeça: elementos básicos de sociologia do futebol. Rio de Janeiro: Irradiação Cultural, 1996.

PIMENTA, M. Novos processos de formação de jogadores de futebol e o fenômeno das "escolinhas": uma análise crítica do possível. In: ALABARCES, P. (Comp.). Peligro de Gol: estudios sobre deporte y sociedad en América Latina. Buenos Aires: CLACSO, 2000.

RIGO, L. C. Memórias de um Futebol de Fronteira. Pelotas: Editora Universitária UFPel, 2004. (Coleção História e Etnias de Pelotas, v. 8).

RIGO, L. C. et al. Notas acerca do futebol feminino pelotense em 1950: um estudo genealógico. Revista Brasileira de Ciências do Esporte, Campinas, SP, v. 29, n. 3. p. $173-188$, maio 2008. 
SANTOS, E. S. dos. A representação dos campos de várzea na cidade: um espaço de memória. História: Questões \& Debates, Curitiba, n 47, p. 203-211, 2007.

SANTOS, M. A. S. Periferia e várzea: um espaço de sociabilidade. In: DA COSTA, M. R. (Org.). Futebol: espetáculo do século. São Paulo: Musa, 1999. p. 117-118.

SENNET, R. O declínio do homem público: as tiranias da intimidade. São Paulo: Companhia das Letras, 1998.

TRIVIÑOS, A. N. S. Introdução à Pesquisa em Ciências Sociais: a pesquisa qualitativa em educação. São Paulo: Atlas, 1987.

WACQUANT, L. J. D. Corpo e Alma: notas etnográficas de um aprendiz de boxe. Rio de Janeiro: Relume Dumará, 2002.

WITTER, J. S. A várzea não morreu. In: MEIHY, J. C. S. B.; WITTER, J. S. (Org.). Futebol e Cultura: coletânea de estudos. São Paulo: IMESP, Arquivo do Estado, 1982. p. 101-104.

Apoio Ministério do Esporte (Rede CEDES) e CNPq

Recebido em: 04.10.2009

Aprovado em: 04.07.2010

Wovimento, Porto Alegre, v. 16, n. 03, p. 155-179, julho/setembro de 2010. 